\title{
Meckel's Diverticulum. A Case Report
}

\author{
Divertículo de Meckel. Reporte de Caso
}

Sampath Madhyastha; Latha V. Prabhu; Saralaya V. \& Prakash

MADHYASTHA, S.; PRABHU, V. L.; SARAlAYA, V. \& PRAKASH. Meckel's diverticulum. A case report. Int. J. Morphol., 25(3):519-522, 2007.

SUMMARY: Meckel's diverticulum is the most prevalent congenital anomaly of the gastrointestinal tract. It might remain completely asymptomatic or may mimic some disorders like Crohn's disease, Appendicitis and peptic ulcer diseases. A Meckel's diverticulum was found during routine dissection. A brief review of this anomaly, its embryological explanation, and probable clinical implications with its management is discussed in this report.

KEY WORDS: Meckel's diverticulum; Congenital gastrointestinal anomalies; Dissection.

\section{INTRODUCTION}

The diverticulum ilei or Meckel's diverticulum is the most common congenital anomaly of the gastrointestinal tract. This persistent part is normally present in early fetal life as the proximal part of the vitellointestinal duct, which usually disappears later.

The incidence of Meckel's diverticulum in the general population has been estimated to be about two percent (Standring, 2005). Reports from autopsy and retrospective studies range from 0.14 to 4.5 percent (Ludtke et al., 1989; DiGiacomo et al., 1993). Although Meckel's diverticulum occurs equally in both the sexes, it may cause complications more frequently in males (Arnold \& Pellicane, 1997; Mackey \& Dineen, 1983; Cullen et al., 1994) and therefore is more often diagnosed in males. A fifteen-year study stated that the incidence of complications decreases with age (Soltero $\&$ Bill, 1976). Two retrospective studies of patients diagnosed with Meckel's diverticulum also reached this conclusion (Leijonmarck et al., 1986).

A population based study (Cullen et al.) from 1950 to 1992 found the incidence of a diverticular complication to be7.4 per 100,000 person - years, translating to a 6.4 percent lifetime risk (lifetime $=80$ years of age ) of a person developing a complication related to the diverticulum. More recently, a ten year retrospective study (Arnold \& Pellicane) also reported an even age distribution in patients with complications.
The diagnosis of the Meckel's diverticulum can be made by Technetium scan. The material used is Technetium - 99m pertechnetate which is injected intravenously; over time it accumulates in the gastric mucosa (DiGiacomo \& Cottone, 1993). When Meckel's scan is non-diagnostic or in patients with non-bleeding presentations, ultrasonography is perhaps the most useful non-invasive method of reaching a diagnosis (Daneman et al., 1998).

\section{CASE REPORT}

The variation was observed during routine dissection of a male cadaver in the dissection hall of department of Anatomy, Kasturba Medical College, Manipal. The history of the individual and cause of the death is not known.

The small intestine and Meckel's diverticulum were dissected and our findings were recorded by photography. A small portion of the wall of the diverticulum was processed for histological study and stained with haematoxylin and eosin.

At dissection the following features were noted.

- The Meckel's diverticulum presented itself $58 \mathrm{~cm}$ proximal to the ileoceacal junction (Fig. 1).

- Its length was $4.3 \mathrm{~cm}$. 
- Its breadth was $2.1 \mathrm{~cm}$.

- The diverticulum was attached to the ante mesenteric border and was suspended by a small peritoneal extension from the mesentery.

- The blind extremity (tip) of the diverticulum was not connected to abdominal wall or other portion of the intestine.

- The interior showed circular mucous folds, which were similar to that of the proximal part of the ileum (Fig. 2).

- The histological examination showed the presence of short and stout folds of mucous membrane lined by simple columnar epithelium and few goblet cells. Lymphatic follicles were also observed in submucosa. Oxyntic types of cells or pancreatic tissue were not identified.

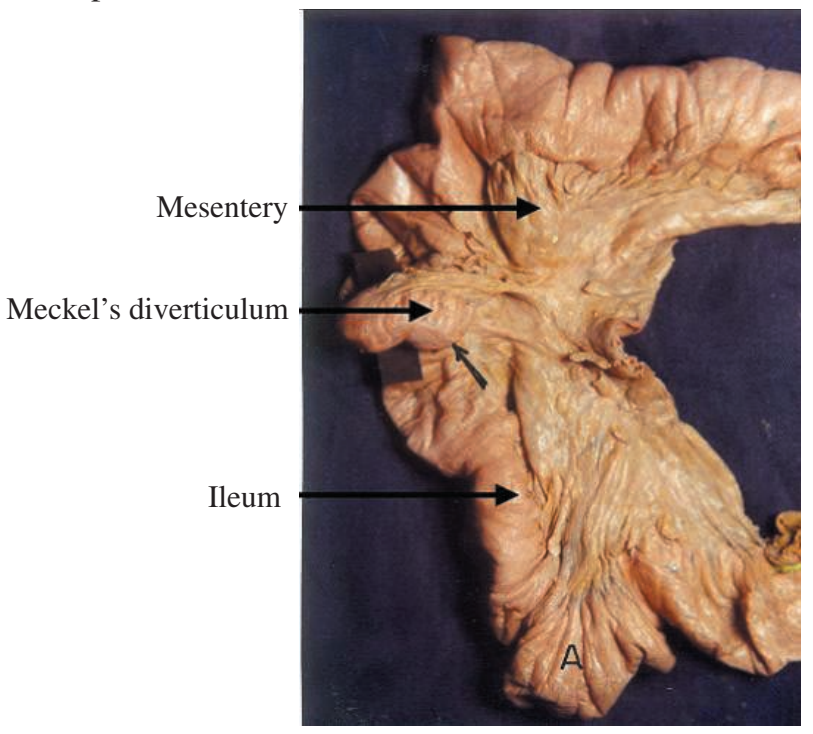

Fig. 1. Meckel's diverticulum

Mucous folds inside the divertculum

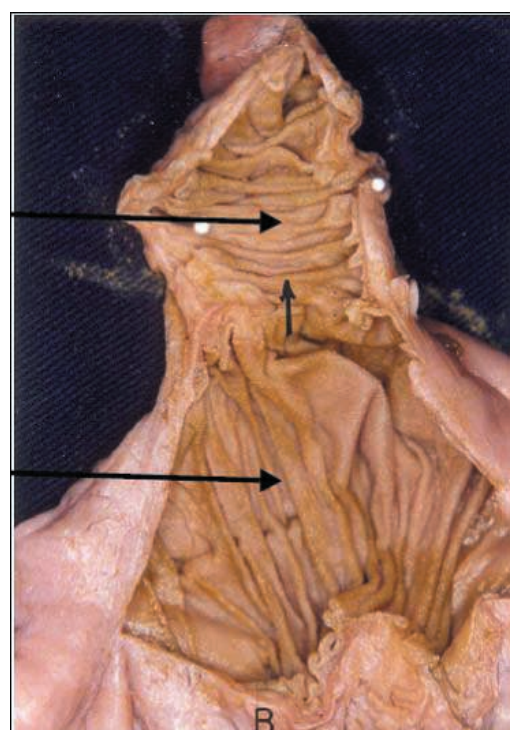

Fig. 2. Interior of the Meckel's diverticulum showing, mucous folds, mesentery Meckel's diverticulum and ileum.

\section{DISCUSSION}

Meckel's diverticlulum is an intestinal diverticulum that results from the failure of the Vitelline duct to obliterate during the fifth week of fetal development (Turgeon \& Barnett, 1990). It contains all the normal layers of the intestinal wall and in approximately 50 percent of the cases, contains tissues from other sites (ectopic tissue), (Turgeon \& Barnett). Meckel's diverticulum occurs in about two percent of the population, making it the most prevalent congenital anomaly of the gastrointestinal tract. It presents itself as a small out pouching from the lower part of the ileum arising from the ante mesenteric border - the part of the intestine lying opposite the mesenteric attachment. Ninety percent of the diverticula are within $90 \mathrm{~cm}$ of the ileoceacal valve, although presence of the diverticula up to $180 \mathrm{cms}$ from the ileocaecal valve have been reported (Williams, 1981). Its caliber is generally similar to that of ileum and its blind extremity may be free or may be connected with abdominal wall or with some other portions of the intestine by a fibrous band.

In the present report the Meckel's diverticulum presented itself $58 \mathrm{~cm}$ proximal to the ileocecal junction. It had a length of $4.3 \mathrm{~cm}$ and breadth of $2.1 \mathrm{~cm}$. Its interior showed circular mucous folds similar to that of the proximal part of the ileum.

The embryological basis for the Meckel's diverticulum is well known. During early fetal development, the fetal midgut is attached to the yolk sac for nutrition via the omphalomesemteric duct (Mackey \& Dineen). Failure of the most proximal part of this duct to obliterate, results in the formation of a Meckel's diverticulum (Artigas, 1986). The yolk sac is continuous with the embryo and contains all the layers of the intestinal wall; therefore the diverticulum that forms the yolk sac also contains all the layers of the intestinal wall (Moore \& Persaud, 1993).

Ectopic tissue is found in up to 55percent of Meckel's diverticula (Haubrich et al., 1995). Gastric and pancreatic tissue predominates with corresponding incidences of 60 to 85 percent and 5 to 16 percent respectively (Mackey \& Dineen; Cullen et al.; Garretson \& Frederich, 1990). The highly acidic secretions of gastric tissue may cause ulcerations that often lead to early diagnosis because of symptoms of gastrointestinal bleeding. The alkaline secretions of ectopic pancreatic tissue can also cause ulcerations (Artigas). Reports have cited other tissues such as colonic, duodenal, jejunal, hepatic and endometrial; however these occurrences are quite rare and are not in reports of complications (DiGiacomo \& Cottone; Williams; Garretson \& Frederich). 
Malignancies may also occur but are found in only 0.5 to 4.9 percent of patients with complications of Meckel's diverticulum. Sarcomas are most common neoplasms, followed by carcinoids and adenocarcinomas (DiGiacomo \& Cottone).

The other major complications are hemorrhage, obstruction, intussusception, diverticulitis and perforation. Bleeding is the most common complication in children. Fibrous bands attached to the diverticulum often cause obstruction.

Laparoscopy can be useful in the diagnosis and treatment of Meckel's diverticula. In addition, the laparoscope can be used to remove incidentally discovered diverticula.
The literature has also reported the successful use of laparoscopic diverticulectomy in infants with bleeding Meckel's diverticulum (Sanders; Huang \& Ling, 1993). Gastrointestinal stapling has also been successfully used (DiGiacomo \& Cottone).

Though the presence of Meckel's diverticulum was said to be common in two percent of individuals, we identified this diverticulum for first time in the last 12 years in about 150 cadavers. Hence it is necessary to report such anomaly, whenever it encountered in surgical procedures or cadaver dissection. The present paper will highlight the incidence, the embryological basis and related clinical implications of the Meckel's diverticulum.

MADHYASTHA, S.; PRABHU, V. L.; SARAlAYA, V. \& PRAKASH. Divertículo de Meckel. Reporte de caso. Int. J. Morphol., 25(3):519-522, 2007.

RESUMEN: El divertículo de Meckel es la anomalía congénita más prevalente del tracto gastrointestinal. Puede ser un remanente totalmente asintomático o puede provocar algunos desórdenes como la enfermedades de Crohn, apendicitis y úlcera péptica. Un divertículo de Meckel fue encontrado durante una disección de rutina. Una breve revisión de esta anomalía, su explicación embriológica y probables implicaciones clínicas fueron discutidas en este trabajo.

PALABRAS CLAVE: Divertículo de Meckel; Anomalía gastrointestinal congénita; Disección.

\section{REFERENCES}

Arnold, J. F. \& Pellicane, J.V. Meckel's diverticulum: a tenyear experience. Am. Surg., 63:354-5, 1997.

Artigas, V.; Calabuig, R.; Badia, F. et al. Meckel's diverticulum: value of ectopic tissue. Am Surg., 151:6314, 1986 .

Cullen, J. J.; Kelly, K. A.; Moir, C. R. et al. Surgical management of Meckel's diverticulum. An epidemiologic, population based study. Ann Surg., 220:564-9, 1994.

Daneman, A.; Lobo, E.; Alton, D. J. \& Shuckett, B. The value of sonograhpy, CT and air enema for detection of complicated Meckel's divertuculum in children with nonspecific clinical presentation. Pediatr. radiol., 28:928-32, 1998.

DiGiacomo, J. C. \& Cottone, F. J. Surgical treatment of Meckel's diverticulum. South Med J., 86:671-5, 1993.

Garretson, D. C. \& Frederich, M. E. Meckel's diverticulum. Am. Fam. Physician., 42:115-9, 1990.

Haubrich, W. S.; Schaffner, F.; Berk, J. E. \& Bockus, H. L.
Gastroenteroly. 5th ed. Philadelphia, Saunders, 1995. V. 2. pp. 912-4.

Huang, C. S. \& Lin, L. H. Laproscopic Meckel's diverticulectomy in infants: report of three cases. $J$. Pediatr. Surg., 28:1486-9, 1993.

Leijonmarck, C. E.; Bonman-Sandelin, K.; Frisell, J. \& Raf, L. Meckel's diverticulum in the adult. $B r$. J. Surg., 73:146-9, 1986.

Ludtke, F. E.; Mende, V.; Kohler, H. \& Lepsien, G. Incidence and frequency of complications and management of Meckel's diverticulum. Surg. Gynecol. Obstet., 169:537-42, 1989.

Mackey, W. C. \& Dineen, P. A fifty - year experience with Meckel's diverticulum. Surg. Gynecol. Obstet., 156:5664, 1983.

Moore, K. L. \& Persaud, T.V. The developing human. $5^{\text {th }}$ ed. Philadelphia, Saunders. 255-7, 1993.

Sanders, L. E. Laparoscopic treatment of Meckel's diverticulum. Obstruction and bleeding managed with minimal morbidity. Surg Endosc., 9:724-7, 1995. 
Soltero, M. J. \& Bill, A. H. The natural history of Meckel's diverticulum and its relation to incidental removal. 32:168-73, 1976.

Susan Standring. Gray's Anatomy. $39^{\text {th }}$ ed. The anatomical basis of clinical practice. London, Elsevier Churchill Livingstone. 2005.

Turgeon, D. K. Barnett, J. L. Meckel's diverticulum. Am. J. Gastroenterol., 85:777-81, 1990.

Williams, R. S. Management of Meckel's diverticulum. $B r$. J. Surg., 68:477-80, 1981.
Correspondence to:

Dr. Sampath Madhyastha

Associate Professor

Department of Anatomy

Kasturba Medical College, Mangalore

575001

INDIA

Phone: +91 824 2423452/2423654, 2422271

Fax: +91 8242428183

Email: madhyast@yahoo.com

Received: 06-02-2007

Accepted: 18-05-2007 